\title{
The Effects of Eccentric Muscle Contraction Program on Walking and Balance Ability of Children with Brain Lesion Disorder
}

\author{
Sang-Hyup Song ${ }^{1 *}$
}

प4FPXРQG GVFSTIZ

3FDFJFE[December 24, 2018

" DFQQFE $\square$ January 17, 2019

IVCJII FE[POJOF]January 31, 2019

\section{, FZXPET}

Balance

Brain Lesions

Eccentric Muscle Contraction

Walking
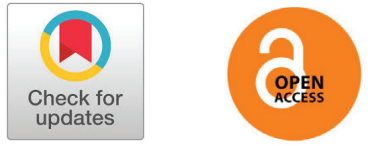

\section{" \#453" \$5}

$0 \#+\$ 5 * 7$ The purpose of this study was to identify the effects of eccentric muscle contraction program on walking and balance ability of children with brain Lesion disorder.

. \$5) $0 \% 4$ Two children with brain Lesion disorder were participated in this study. The subjects are spasticity, which makes the body too tight or difficult to adjust. The numbness of the limbs or numbness of the muscles of the legs due to involuntary exercise paralysis is frequently changed, and excessive shaking occurs in addition to the intended actions. The intelligence estimated by the Intelligence Test and VisualMotor Integration Development Test (VMI) is equivalent to Severe Mental Retardation Level (IQ / VMI: less than 35 ). The test was conducted for 12 weeks and the subjects had eccentric muscle contraction program for 50 minutes a day and twice a week. To assess the walking and balance ability subjects were tested on following items: Walking ability for $6 \mathrm{~m}$ forward walk test, $10 \mathrm{~m}$ forward walk test, $3 \mathrm{~m}$ backward walk test, stair up 4 steps and stair down 4 steps. Balance ability for single leg stand in opened eyes and closed eyes were measured.

3\$46-54 In the case of subject $A$ and $B, 6 \mathrm{~m}$ forward walk test was reduced by $6.2 \%(A), 3.2 \%(B)$ and $10 \mathrm{~m}$ forward walk test was reduced by $6.6 \%(A), 6.2 \%(B) .3 \mathrm{~m}$ backward walk test reduced by $4.2 \%(A), 1.3 \%(B)$ compared to the pre-test. Stair up 4 steps was reduced by $2.9 \%(A), 4.3 \%(B)$ and stair down 4 steps was reduced by $6.7 \%(A), 3.2 \%(B)$ than the pre - test. Single leg stand in opened eyes was increased by $21.6 \%(A)$, $24.6 \%(B)$ in the right foot and the left foot was increased by $20.2 \%(A), 35.8 \%(B)$. Single leg stand in closed eyes increased by $8.1 \%(A), 17.5 \%(B)$ in the right foot and the left foot was increased by $10.9 \%(A), 11.1 \%(B)$.

$\$ 0 / \$-64 \% / 4$ Those result show that the eccentric muscle contraction exercise program had positive influence in the walking and balance ability for children with brain lesion disorder.

(c) The Asian Society of Kinesiology and the Korean Academy of Kinesiology $\square \boldsymbol{d}$

뇌병변 장애인들의 특징은 여러 가지가 있지만 그 중 운동장애의 측면에서 살펴보면 비대칭적 자세, 균형능력 의 결함, 체중이동 및 섬세한 기능을 수행하기 위해 필 수적인 특수한 운동요소가 상실되어 있다[1]. 그 중 근

*Correspondence: Sang-Hyup Song, Physical Education, Seowon University, 377-3 Musimseoro, Heungdeok-gu, Cheongju, Chungbuk, 361-742; E-mail: yohyupl@ hanmail.net
육의 약화나 근긴장 그리고 불수의 동작 으로 인해 일상 적인 활동에 많은 제약이 따르고 있으며[2], 비대칭적인 자세 및 신체의 불균형과 같은 하지 정렬의 문제와 체중 이동능력 감소, 운동실조 등의 문제로 독립적인 보행에 어려움을 격고 있다[3]. 이처럼 뇌병변 장애인들은 일 상생활에서 기립과 보행능력에 장애를 받아 이동능력에 제한이 생기고 결과적으로 삶의 질을 떨어뜨리는 원인 으로 작용하고 있어 뇌병변 장애인들의 보행과 평형능 
력을 개선하기 위한 노력은 절실히 요구되고 있다[4].

뇌병변 장애인들의 보행에 부정적인 영향을 끼치는 다양한 원인 중에서 가장 높은 빈도를 보이는 요인은 뇌 손상으로 인해 발생하는 신경장애와 근골격의 강직 및 보행 장애로 근긴장이 계속적으로 이루어지게 되고, 근 육의 활성이 적절한 시기와 순서로 이루어지지 못하게 한다. 이러한 원인으로 인해 자세조절이 불안정하게 되 며, 운동기능이 적절히 수행하지 못하게 된다[5]. 이에 하지의 근신경 발달을 통한 근력개선을 위한 운동방법 이 필요할 것으로 생각된다. 선행연구를 살펴보면 YoO et al. [6]은 뇌성마비 아동을 대상으로 트레드밀에서 보행운동을 수행한 결과 하지정렬 상태에 변화를 주었 고 보행능력 향상이 되었음을 보고하였고 체중이동 운 동의 중요성을 인지하고 뇌병변 장애인을 대상으로 체 중이동 운동을 진행함으로써 평형능력, 근활성도, 좌우 대칭적 자세 및 보행능력이 개선되었음을 확인하였다. 아울러 체중이동 능력은 보행과 상관관계가 있으며, 보 행능력을 회복하기 위해서는 올바른 자세조절과 양측 하 지로의 체중이동이 가능하여야 한다고 보고하였다[7]. 또한 Dettmann et al. [8]은 환측 하지로 무게중심을 이동하지 못하게 되면 불안정한 보행의 원인이라 하였 으며, 보행능력을 회복하기 위해서는 기립자세 유지와 조절을 할 수 있어야 하고 더불어 양측 하지로 체중이 동이 가능하여야 한다고 하였다. 따라서 뇌병변 장애인 의 보행과 평형능력의 향상은 일상생활과 더불어 사회 복귀를 위한 중요한 목표이다.

일반적으로 뇌병변 장애인을 대상으로 한 운동의 유 형에는 보행, 불안정한 지면에서의 체중이동 운동, 수 중운동, 승마운동 등의 운동으로 접근하여 효과를 규명 하고자 하였다. 하지만 뇌병변 장애인의 약해진 근력과 높아진 근긴장도 그리고 스스로 근육을 조절하지 못하 는 불수의 동작의 특성을 고려해 볼 때 근육을 사용하는 기초적인 단계에서의 근수축 방법을 학습하는 것은 중요 한 해결과제라 생각된다. 이처럼 다양한 뇌병변 장애인 의 신체적 특징과 장애 정도에 적합한 운동 프로그램의 도입이 시급하며 이를 위한 근본적인 근수축 방법에 따 른 운동 프로그램의 개발은 매우 중요하다고 생각한다.

근력발달을 위한 기본적인 근수축 방법으로는 단축 성 근수축(concentric muscle contraction)과 신장성 근수축(eccentric muscle contraction)을 포함하고 있 는 등장성(isotonic) 운동이 있으며 이중 신장성 근수축
운동의 장점은 단축성 근수축과 비교하여 피로를 덜 느 끼고[9], 근육활동 시 발현되는 운동단위가 적음에도 불 구하고 큰 장력을 발휘할 수 있으며 산소수요량, 에너 지 소비량, 젖산 생성량이 적은 것으로 이미 잘 알려져 있다[10]. 이러한 선행연구의 근거에 따라 뇌병변 장애 아동을 대상으로 신장성 근수축 운동을 강조하는 운동 프로그램은 일상생활에 필요한 체력향상에 효과가 있 을 것이라 생각된다.

이에 이 연구에서는 뇌병변 장애아동을 대상으로 신 장성 근수축운동 프로그램을 적용하고 보행과 평형능력 의 변화를 분석하여 뇌병변 장애아동을 위한 운동 프로 그램 개발을 위한 기초자료를 제시하고자 한다.

\section{연구방법}

\section{연구대상}

이 연구의 대상자는 충청남도에 소재하고 있는 $\mathrm{S}$ 센 터에 소속되어있는 뇌병변 장애아동 2명을 대상으로 하였다. 뇌병변 장애인은 뇌성마비, 외상성 뇌손상, 뇌 졸중 등 뇌의 기질적 병변으로 인한 신체적 장애로 보 행 또는 일상생활에서 제약을 받는 사람으로 이 연구의 대상자는 장애인복지법의 뇌병변 장애로 진단을 받은 장애아동을 대상으로 하였다. 대상자 $\mathrm{A}$ 와 $\mathrm{B}$ 는 모두 몸 이 지나치게 긴장하거나, 신체조정이 어려운 경직형 (spasticity)으로 불수의 운동마비로 사지가 떨리거나 근긴장도가 수시로 변해 의도한 행동 이외에 과도한 흔 들림이 많이 나타나고 의도적인 움직임을 시도할 때 많이 나타나기 때문에 기능적 동작을 방해하고 균형 감각과 위치감각이 없어 협응동작에 어려움이 있는 상태이며, 대상자 $\mathrm{A}$ 는 지능검사 및 시각-운동 통합 발달 검사(VMI)로 추정한 지능이 Severe Mental Retardation Level(IQ/ VMI: 35 미만)에 해당하는 학 생이다. 이 연구에 참여하는 대상자와 부모에게 이 연 구의 취지와 내용에 대하여 충분히 설명하고 참가 동 의를 받았다. 대상자의 신체적 특성은 다음과 같다 $<$ Table 1 >.

연구대상자 $\mathrm{A}$ 는 뇌병변 장애와 지적장애를 중복으 로 진단받은 아동으로 일상생활측면에서 타인의 지시 를 따르거나, 본인 스스로 앉거나 서기, 걷기가 가능 하지만 협응성의 부족으로 자연스러운 움직임에 제한 이 있으며 전반적인 동작이 연속적으로 이루어지지 
않는다는 문제점이 관찰되고 있다. 보행 중에는 빈번하게 넘어지거나 장시간 보행 시 쉽게 지치거나 피로감을 표현 하고 있어 적극적인 신체활동의 참여가 어려운 상황이 다. 특히, 무릎관절을 적절한 관절의 가동범위 $(\mathrm{ROM})$ 에서 굽힘( lexion)하지 못하고 발의 보폭이 작아 조급한 상태 에서 자연스럽지 못한 걸음을 유지하고 있다. 또한 높 은 곳에서 낮은 곳으로의 이동 시 무릎의 굽힘과 폄(extension)동작이 원활하지 않아 충격을 흡수하고 자세를 유지하는데 어려움이 있는 상태이다. 계단을 이용 하여 이동할 때는 손잡이 레일을 잡고 계단을 오르고 내 릴 수는 있지만 주로 왼발만 사용하여 한 번에 한 칸씩 움 직이며 달리거나 점프동작을 수행하는데 어려움이 있는 상태이다.

연구대상자 $\mathrm{B}$ 는 뇌병변 장애아동으로 아킬레스힘줄 (achilles tendon)과 장딴지근(gastrocnemius muscle)의 단축으로 발바닥쪽굽힘(plantar lexion) 상태로 보행을 하고 있으며, 평지에서의 보행 시 종종 넘어지는 동작을 보이며 계단을 올라갈 때에는 주변의 도움을 받아야 할 정도로 이동능력이 지체되어 있다. 경사로에서는 손잡이 를 잡지 않고 오르내릴 수 있으나 계단은 손잡이를 잡고 한 칸씩 이동하는 모습을 보이고 있으며, 고정식 자전거 에서의 페달링은 가능하나 연속적이고 일정한 리듬으로 유지하기는 어려운 상태이다.

Table 1. Physical characterlistics of the subjects.

\begin{tabular}{ccc}
\hline & Subject A & Subject B \\
\hline Gender & Male & Male \\
Age(yrs) & 13 & 13 \\
Height $(\mathrm{cm})$ & 138.2 & 140.7 \\
Body weight(kg) & 38.6 & 41.5 \\
BMI(kg/m2) & 20.21 & 20.96 \\
\hline
\end{tabular}

\section{측정 도구 및 방법}

이 연구의 측정 도구와 방법은 뇌병변 장애아동에게 적합하도록 구성할 수 있도록 특수체육 전문가, 특수교 육 전문가, 운동재활 전문가 3 인으로 구성된 전문가 집 단의 검증을 받고 시행하였다.

\section{보행능력 측정 변인}

보행측정은 Rehm-Gelin et al. [12]이 사용한 방법
으로써 주로 노인이나 장애인이 갖는 일상생활의 불편 한 정도를 측정하기 위하여 보행동작을 수행하는데 소 요되는 시간을 측정하였다. 측정항목으로는 $6 \mathrm{~m}$ 걷기 (6 $\mathrm{m}$ forward walk test), $10 \mathrm{~m}$ 걷기 $(10 \mathrm{~m}$ forward walk test), $3 \mathrm{~m}$ 뒤로 걷기 $(3 \mathrm{~m}$ backward walk test), 4 개 계단 오르기(stair up 4 steps) 그리고 4개 계단 내려오기(stair down 4 steps) 동작을 실시하였으며, 이 측정항목의 신뢰도 를 평가하는 급내 상관계수는 0.97이다.

6M 걷기 검사(6 m forward walk test) 시작부터 종료지점까지의 거리 $6 \mathrm{~m}$ 를 색상 테이프를 이용하여 평평한 지면에 붙여놓고 대상자가 이동하는 동선을 제 시하였다. 시작이라는 신호와 함께 걷기 시작하여 양 발이 모두 종료선을 통과하는데 소요되는 시간을 측정 하였다. 측정은 2 회 실시한 후 그 평균값을 검사결과로 사용하였다.

$10 \mathrm{M}$ 걷기 검사(10 m forward walk test) 시작부터 종료지점까지의 거리 총 $13 \mathrm{~m}$ 구간 중 시작 지점과 도 착 지점 각 $1,5 \mathrm{~m}$ 의 구간을 제외한 나머지 $10 \mathrm{~m}$ 구간 을 최대 보행 속도로 이동하는 시간을 측정하였다. 측정 은 2회 실시한 후 그 평균값을 검사 결과로 사용하였다.

\section{$3 \mathrm{M}$ 뒤로 걷기 검사(3 m backward walk test) 시} 작부터 종료지점까지 $3 \mathrm{~m}$ 를 색상 테이프를 이용하여 평평한 지면에 붙여놓고 대상자가 이동하는 동선을 제 시하였다. 시작이라는 신호와 함께 뒤로 걷기 시작하 여 양 발이 모두 종료선을 통과하는데 소요되는 시간 을 측정하였다. 측정은 2 회 실시한 후 그 평균값을 검 사결과로 사용하였다.

4개 계단 오르기(stair up 4 steps) 4 개의 계단을 오르는데 소요되는 시간을 측정하는 검사로써, 측정자 의 시작이라는 신호와 함께 4 개 계단으로 오르기 시작 하여 양 발이 모두 마지막 4 번째 계단에 도달하기까지 의 시간을 측정하였다. 측정은 2 회 실시한 후 그 평균 값을 검사결과로 사용하였다.

4개 계단 내려오기(stair down 4 steps) 4 개 계단 을 내려오는데 소요되는 시간을 측정하는 검사로써, 측정자의 시작이라는 신호와 함께 4 개 계단을 내려오 기 시작하여 양 발이 모두 마지막 바닥에 도달하기까 지의 시간을 측정하였다. 측정은 2 회 실시한 후 그 평 균값을 검사결과로 사용하였다. 


\section{평형능력 측정 변인}

평형능력 측정은 Sung[13]이 사용한 방법으로써 주로 노인과 장애를 가지고 있는 대상자의 평형능력을 측정하였다. 대상자의 운동 중 평형능력의 안정성을 유지할 수 있는 기능을 평가하는 평형성 검사는 안정 된 지면 위에서 한발을 들고 안정적인 자세로 유지하 는가를 측정·평가하였다.

\section{눈뜨고 외발서기 (single leg stand in opened eyes)} 측정에 앞서 측정방법과 자세를 대상자에게 시범을 보 이고 지도자의 도움을 받아 양팔을 옆으로 들고 준비자 세를 준비하였다. 준비가 끝나면 눈을 뜬 상태에서 서서 히 한발을 들고 눈을 감은 후 안정된 자세를 유지한다. 몸을 심하게 움직이거나 다리를 땅에 내리거나 팔을 내 리게 되면 검사를 종료하였다. 총 2회 실시하여 그 평균 값을 검사결과로 사용하였다.

\section{눈감고 외발서기 (single leg stand in closed eyes)}

측정에 앞서 측정방법과 자세를 대상자에게 시범을 보이 고 지도자의 도움을 받아 양팔을 옆으로 들고 준비자세 를 준비하였다. 준비가 끝나면 서서히 한발을 들고 눈을 감은 후 안정된 자세를 유지한다. 몸을 심하게 움직이거 나 다리를 땅에 내리거나 팔을 내리게 되면 검사를 종 료하였다. 총 2 회 실시하여 그 평균값을 검사결과로 사용 하였다.

\section{운동 프로그램}

이 연구의 신장성 근수축운동 프로그램은 1회 50 분,주 2 회, 총 12 주간 수행하였다. 신장성 근수축운동 프 로그램은 Bubbico \& Kravitz [14]의 연구에서 실시한 프로그램을 뇌병변 장애 아동이 수행할 수 있는 동작으 로 구성하여 수정 보완하였다. 운동의 빈도는 $\mathrm{ACSM}$ 에서 장애가 있는 청소년과 어린이의 경우 주 3 회를 권장 하고 있지만, 이 연구에 참여한 대상자의 체력수준을 고 려하였을 때 주 2회 실시하여 운동의 효과가 있었다는 선 행연구[15]에 근거하여 빈도를 설정하였다. 또한 운동 강도는 프로그램 단계에 따라 $\mathrm{RPE}$ 를 기준으로 가볍다 (11)에서 약간 힘들다(14)로 설정하였다.

준비운동은 트레드밀을 이용하여 10 분간 진행하였다. 지도자는 트레드밀에서 대상자와 시선을 마주하게 위 치하고 천천히 걷기 $(3 \mathrm{~km} / \mathrm{h})$ 시작하여 가볍게 달리기 $(8 \mathrm{~km} / \mathrm{h})$ 까지의 과정을 동일한 자세로 지도하였다. 이 중,
가속구간에서는 지도자는 양손을 잡아주어 정상 속도 에 도달할 수 있도록 유도하였고 신장성 근수축을 수 행하는 감속구간에서는 대상자가 스스로 달리는 속도 를 감소할 수 있도록 지도하였다. 장애아동의 하지근 력 발달과 신장성 근수축 동작을 강화시키기 위해 스쿼 트, 스텝박스 내리기, 허들점프를 수행하였다. 스쿼트 는 양쪽 발을 어깨 넓이로 간격으로 조정하고 올라오 는 단축성 구간(2초)과 내려가는 신장성 구간(5초)동 안 수행하였으며, 지도자는 운동 중 대상자의 양손을 잡고 균형을 유지하며 정확한 동작으로 수행할 수 있 도록 지도하였다. 스쿼트 동작 시 올라오는 단축성 구 간에서는 두발을 이용하여 무릎을 펴면서 올라오고 내 려가는 신장성 구간에서는 외발로 내려가기 동작으로 신장성 근수축운동을 강화시켰다. 스텝박스 내리기 동 작은 $20 \mathrm{~cm}$ 높이의 스텝박스를 이용하였다. 스텝박스 오르기 동작은 지도자의 보조를 받아 박스 위에 올라 선 후에 스스로 내려가는 동작으로 운동초기에는 한발 씩 내리는 동작에서 시작하여 향상기에는 두발로 점프 하여 내리는 방법으로 플라이오메트릭적 요소를 가미하 여 신장성 근수축 방법의 특징을 극대화시켜 지도하였 다. 허들점프는 $16 \mathrm{~cm}$ 와 $23 \mathrm{~cm}$ 높이의 미니 허들을 이 용하여 두발을 이용하여 동시에 점프하여 허들을 넘고 착지 시에도 두발이 동시에 착지할 수 있도록 지도하 였다. 장애아동의 보행안정성 및 고유수용성 증가를 위한 트램폴린에서의 스쿼트 운동은 지면에서 실시한 방법을 동일하게 트램폴린을 이용하여 실시하였다. 운동의 강도는 과부하의 원리와 점증부하의 원리에 따 라 적응기(1-4주, 10회, 2세트, RPE 10), 향상기(5-8 주, 12회, 2세트, RPE 12), 유지기(9-12주, 15회, 3세 트, RPE 14)로 나누어 개인의 체력수준 및 운동 적응 상황에 따라 강도를 증가시키고, 세트 사이에는 대상 자의 특성을 고려하여 2 분간의 휴식시간을 충분히 제 공하였다. 뇌병변 장애아동의 특성상 신장성 근수축 구간에서 동작 유지의 어려움이 있어 운동초기 2 주 동 안은 지도자의 보조기법 도움을 받아 수행하였으나 3 주차부터는 대상자 스스로가 동작을 수행할 수 있도록 최대한 조절하였고, 대상자들이 스스로 수행하기 어려 운 동작들은 지도자의 적극적인 개입을 통하여 정확한 자세가 유지될 수 있도록 하여 안전사고의 위험을 최 
Table 2. Eccentric muscle contraction exercise program.

\begin{tabular}{lll}
\hline Index & Exercise & Intensity \\
\hline Warm-up & Walking and running & \\
& & \\
& Squat (both foot) & $<1-4$ week $>$ \\
& Squat (2up-1down) & 10 reps X 2 sets, RPE 10 \\
& Step down & 12 reps X 2 sets, RPE 12 \\
Eccentric muscle & Hurdle jump & $<9-12$ week $>$ \\
contraction & Squat (both foot with & 15 reps X 3 sets, RPE 14 \\
exercise & trampoline) & $<$ rest $>$ \\
& Squat (2up-1down & 2 min between set \& \\
& with trampoline) & exercise \\
& & \\
\hline
\end{tabular}

소화 할 수 있도록 주의하였다. 신장성 근수축운동 프 로그램은 <Table 2>와 같이 제시하였다.

\section{자료처리}

이 연구에서 측정 - 수집된 자료는 사전검사를 실시하 고 12 주간의 신장성 근수축운동 프로그램을 적용한 후 사후검사를 실시하였으며 사전, 사후의 측정결과와 증 감의 차이를 비교하고 비율(\%)로 산출하였다.

\section{결과}

\section{보행능력의 변화}

신장성 근수축운동 프로그램을 실시 한 후 보행능력 을 검증한 결과는 <Table 3 >과 같다. 대상자 $\mathrm{A}$ 의 $6 \mathrm{~m}$ 걷기는 사전검사 시 8.53초에서 사후 검사 시 7.29 초 로 1.24 초 $(-6.2 \%)$ 감소하였고, $10 \mathrm{~m}$ 걷기는 사전검사 시 12.82 초에서 사후검사 시 11.49 초로 1.33 초(-6.6\%) 감소하였다. $3 \mathrm{~m}$ 뒤로 걷기는 사전검사 시 9.12 초에서 사후 검사 시 8.27 초로 0.85 초 $(-4.2 \%)$ 감소하였다. 4 개 계단 오르기는 사전검사 시 6.52 초에서 사후검사 시 5.93 초로 0.59 초 $(-2.9 \%)$ 감소하였고, 4 개 계단 내려가 기는 사전검사 시 6.93 초에서 사후 검사 시 5.58초로 1.35 초 $(-6.7 \%)$ 감소하였다. 대상자 $\mathrm{B}$ 의 $6 \mathrm{~m}$ 걷기는 사 전검사 시 7.98 초에서 사후 검사 시 7.34 초로 0.64 초 $(-3.2 \%)$ 감소하였고, $10 \mathrm{~m}$ 걷기는 사전검사 시 11.77 초에서 사후검사 시 10.53초로 1.24 초(-6.2\%) 감소하 였다. $3 \mathrm{~m}$ 뒤로 걷기는 사전검사 시 7.49 초에서 사후 검사 시 7.23 초로 0.26 초 $(-1.3 \%)$ 감소하였다. 4 개 계 단 오르기는 사전검사 시 6.19초에서 사후검사 시 5.32 초로 0.87 초 $(-4.3 \%)$ 감소하였고, 4 개 계단 내려가기는
Table 3. Changes in gait ability of pre and post 12 weeks eccentric muscle contraction exercise.

\begin{tabular}{ccccc}
\hline Index & Subject & Pre & Post & Decrease \\
\hline 6 m forward walk test & A & 8.53 & 7.29 & -1.24 \\
(sec) & B & 7.98 & 7.34 & -0.64 \\
10 m walking test & A & 12.82 & 11.49 & -1.33 \\
(sec) & B & 11.77 & 10.53 & -1.24 \\
3 m backward walk & A & 9.12 & 8.27 & -0.85 \\
test (sec) & B & 7.49 & 7.23 & -0.26 \\
stair up 4 steps (sec) & A & 6.52 & 5.93 & -0.59 \\
stair down 4 steps & B & 6.19 & 5.32 & -0.87 \\
(sec) & A & 6.93 & 5.58 & -1.35 \\
& B & 6.36 & 5.72 & -0.64 \\
\hline
\end{tabular}

사전검사 시 6.36초에서 사후 검사 시 5.72초로 0.64초 $(-3.2 \%)$ 감소하였다.

\section{평형능력의 변화}

신장성 근수축운동 프로그램을 실시 한 후 평형능력 을 검증한 결과는 <Table 4 >와 같다. 대상자 A의 눈 뜨고 외발서기는 오른발의 사전검사 시 3.42 초에서 사 후 검사 시 7.74 초로 4.32 초(21.6\%) 증가하였고, 왼발 은 4.29초에서 사후 검사 시 8.33초로 4.04초(20.2\%) 증가하였다. 눈 감고 외발서기는 오른발의 사전검사 시 1.59 초에서 사후 검사 시 3.21초로 1.62초(8.1\%) 증가 하였고, 왼발은 2.75 초에서 사후 검사 시 4.93 초로 2.18 초(10.9\%) 증가하였다. 대상자 B의 눈 뜨고 외발서기는 오른발의 사전검사 시 3.63 초에서 사후 검사 시 8.55초 로 4.92초(24.6\%) 증가하였고, 왼발은 6.35초에서 사후 검사 시 13.52 초로 7.17 초(35.8\%) 증가하였다. 눈 감고 외발서기는 오른발의 사전검사 시 1.38 초에서 사후 검사 시 4.88초로 3.50 초(17.5\%) 증가하였고, 왼발은 1.93초 에서 사후 검사 시 4.16 초로 2.23 초(11.1\%) 증가하였다.

\begin{tabular}{|c|c|c|c|c|}
\hline Index & Subject & Pre & Post & Increase \\
\hline \multirow{4}{*}{$\begin{array}{l}\text { Single leg stand in } \\
\text { opened eyes (sec) }\end{array}$} & \multirow{2}{*}{ A } & 3.42 & 7.74 & 4.32 \\
\hline & & 4.29 & 8.33 & 4.04 \\
\hline & \multirow{2}{*}{ B } & 3.63 & 8.55 & 4.92 \\
\hline & & 6.35 & 13.52 & 7.17 \\
\hline \multirow{4}{*}{$\begin{array}{l}\text { Single leg stand in } \\
\text { closed eyes (sec) }\end{array}$} & \multirow{2}{*}{ A } & 1.59 & 3.21 & 1.62 \\
\hline & & 2.75 & 4.93 & 2.18 \\
\hline & \multirow{2}{*}{ B } & 1.38 & 4.88 & 3.50 \\
\hline & & 1.93 & 4.16 & 2.23 \\
\hline
\end{tabular}




\section{논의}

이 연구는 신장성 근수축 운동 프로그램이 뇌병변 장 애아동의 보행과 평형능력에 어떠한 영향을 미치는지 알 아봄으로써 뇌병변 장애아동을 위한 신장성 근수축운동 프로그램의 적용 가능성을 살펴보고자 하였으며, 연구 대상자A와 B의 보행능력 $(6 \mathrm{~m}$ 걷기, $10 \mathrm{~m}$ 걷기, $3 \mathrm{~m}$ 뒤 로 걷기, 4 개 계단 오르기, 4 개 계단 내려가기)과 평형 능력(눈뜨고 외발서기, 눈감고 외발서기) 개선에 긍정적 인 효과가 있는 것으로 나타났다. 따라서 신장성 근수축 운동 프로그램은 뇌병변 장애아동의 보행능력과 평형능 력을 개선시킬 가능성이 시사되었다.

신체적 장애가 있는 사람에게 보행능력은 일상생활 중 독립적인 생활을 영위하고 삶의 질을 향상시키기 위 하여 가장 선행되어야 하는 요소라 할 수 있다. 이 연 구에서 $6 \mathrm{~m}$ 걷기, $10 \mathrm{~m}$ 걷기 그리고 $3 \mathrm{~m}$ 뒤로 걷기를 측 정한 결과 대상자 $\mathrm{A}$ 와 $\mathrm{B}$ 모두 측정기록이 감소되어 보 행능력이 향상되었다. 선행연구를 살펴보면 Yoo et al. [16]은 편마비 장애인를 대상으로 유산소운동과 무산 소운동을 결합한 복합운동을 수행하여 $6 \mathrm{~m}$ 걷기와 $3 \mathrm{~m}$ 뒤로 걷기에서 각각 $17 \%$ 씩 감소되어 보행능력에 긍정 적인 효과가 나타났다고 보고하였으며, Shin \& Song [17]은 뇌성마비 아동들을 대상으로 순환식 운동을 진 행한 결과 대동작 기능, 보행속도 및 균형능력 향상에 긍정적으로 도움이 되었다고 하였다.

이 연구에서 대상자 $\mathrm{A}$ 와 $\mathrm{B}$ 의 사전 측정 시 보행자 세의 불안정성과 흔들림으로 인해 넘어지거나 중심을 유지하는데 시간이 지체되어 보행에 어려움이 있었지 만 트레드밀에서 저속으로 걷기 $(3 \mathrm{~km} / \mathrm{h})$ 와 달리기 $(8 \mathrm{~km} / \mathrm{h})$ 를 통하여 가속과 감속의 반복적인 움직임을 통해 근력 조절과 운동단위 조절능력 그리고 고유수 용감각 조절작용을 통해 체중 중심이동 능력이 향상 된 것으로 생각한다. Ko et al. [18]은 경직성 뇌성마 비 아동 25명을 대상으로 전신진동자극훈련을 6주 간 진행한 결과 $10 \mathrm{~m}$ 보행걷기 검사에서 훈련 전 43.81초에서 훈련 후 30.22초로 감소하였다고 보고 하였고, Cho et al. [19]은 뇌성마비 아동 18명을 대상으로 8주간 가상재활을 병행한 트레드밀 운동을 진행한 결과 $10 \mathrm{~m}$ 걷기 검사와 2 분 걷기 검사에서 유 의한 변화를 주어 보행능력에 효과적이라고 하였다. 이러한 선행연구의 결과로 비추어 볼 때, 신장성 근 수축운동은 지면으로부터 오는 흔들림으로 인해 근
육, 건, 인대의 활성도가 높아져 근육개시시간 단축, 고 유수용성 및 하지근력 향상에 긍정적인 효과를 주어 안정적으로 더 강한 추진력이 생겨 보행능력이 개선된 것으로 생각된다. 또한 뇌병변 장애인의 보행기능을 증가시키는 방법으로 체중이동 및 체중지지가 중요하 다[11]는 주장이 이 연구의 결과를 지지해줄 수 있다 고 생각한다.

이 연구에서 4 개 계단 오르기와 내려가기를 측정한 결과 대상자 $\mathrm{A}$ 와 $\mathrm{B}$ 모두 측정기록이 감소되었으며 이 는 계단 오르기와 내리기 동작이 향상된 것으로 나타 났다. 선행연구를 살펴보면 Kong \& Yoo [20]는 편마 비 장애인을 대상으로 저항성운동을 수행한 결과 4 개 계단 오르기와 내려가기는 운동 후에 각각 $36 \%, 30 \%$ 향상되었다고 보고하였고, Taracki et al. [21]은 뇌성 마비 아동을 대상으로 12 주간 닌텐도 wii- it 비디오게 임을 이용한 균형운동을 실시한 결과, 10 개의 계단 오 르기에서 훈련 전 10.32초에서 훈련 후 8.42초로 유의 하게 감소되었다고 보고하였다. 이러한 선행연구의 결 과에 비추어 볼 때, 이 연구에서 제시하고 있는 스쿼트 와 스텝박스 오르내리기 동작을 통해 하지근력이 향 상되어 자세의 흔들림이 감소되고 안정성이 향상되어 기능적인 보행 활동인 계단 오르기 및 내려가기 능력에 긍정적인 영향을 미쳤다고 생각된다. 신장성 근수축 방 법 측면에서의 선행연구를 살펴보면 Del and Thomas [22]는 단축성 수축운동 시 운동단위 발현 비율은 신 장성 수축운동보다 높은 것으로 나타나며, 일부 저강 도의 운동에서 유사한 비율을 보인다고 하였다. 이러 한 이유는 신장성 근수축운동 동안의 전반적인 근육의 장력이 높기 때문이다. 일반적으로 신장성수축의 근력 은 단축성수축의 근력보다 $120 \%$ 높음에도 불구하고 최대근력발현 시 전체 운동단위를 동원하지 않는다고 하였다[23]. 또한, 신장성 근수축운동은 근육의 적응, 근력 발현 능력 그리고 근비대의 측면에서 단축성 근 수축운동과 비교하여 우수한 것으로 알려져 있다. 따라 서 신장성 근수축운동 프로그램을 통하여 대상자들의 발목 관절 주변의 근육을 강화시켰으며 운동단위의 점 증(recruitment)과 발화율( ire rate)의 증가와 더불어 운동강도에 따른 근섬유의 비율 중 type $\Pi b$ 의 단위가 증가한 것으로 생각한다. 이는 뇌병변 장애아동의 근 수축 활동 시 적절한 시기에 근육을 수축시키고 이완 시킬 수 있는 능력이 개선된 것으로 생각한다.

자세를 유지하기 위해서는 체성감각, 시각, 전정계 
정보를 토대로 중추에서 수합 명령하여 근육을 통해 나 타내는 반응으로 설명할 수 있다. 이 연구에서 눈뜨고 외발서기와 눈감고 외발서기를 측정한 결과 대상자 A 와 $\mathrm{B}$ 모두 측정기록이 향상되어 평형능력이 향상된 것 으로 나타났다. 허들점프와 스텝박스 내리기에서 플라 이오메트릭 형태의 운동 중 신장성 근수축운동은 근육 의 길이를 감지하여 뇌에 신호를 보낸 이후에 단축성 수 축을 통하여 근육의 길이 조절을 한다. 이러한 동작이 신경계가 신전-단축주기(stretch-shortening cycle) 에 보다 빠르게 반응하기 위해 적응되는 과정으로[24] 신경근계의 반응 능력을 개선시켜 신경계의 흥분을 증 가시키는 것이다. 이러한 과정을 통하여 신장성 근수 축운동이 뇌병변 장애아동의 평형능력 개선에 효과적 으로 작용했다고 생각한다. 특히 근육의 사전 활성기 (preactivation)가 나타나는 시점을 단축시키고 구심성 신경에서 시작된 자극을 운동신경의 원심성 신경을 거 쳐 효과기인 근육에 도달시키는 근육 반사궁(reex $\operatorname{arc)}$ 반응 시간을 단축시켜[25] 뇌병변 장애아동의 평형성 유지에 긍정적인 영향을 미치는 것으로 생각한 다. 아울러 인체는 움직임을 수행할 때 자세와 운동조 절을 하기 위하여 대뇌 단독으로 수행하는 것이 아니 라 말초신경계와 근육, 척수, 뇌간, 소뇌 및 대뇌 등이 어떤 체계를 이루어 행해지는 것으로 알려져 있으며 [26], 특히 인체가 평형성을 유지하기 위해서는 특정 근육만이 동원되는 것이 아니라 외부자극에 대해 근육 과 신경의 협력반응이 조화를 이루는 것이 뇌병변 자 애아동의 평형성 유지에 중요하다고 생각한다.

대상자의 개인별 변화를 살펴보면 연구대상자 $\mathrm{A}$ 의 보행 시 주된 문제점은 빈번하게 넘어지거나 쉽게 지치 며 무릎을 굽히지 않고 발을 가까이 자주 떼며 보폭이 좁은 상태에서 보행을 유지하고 있으며, 특히 높은 곳 에서 낮은 곳으로의 이동 시 무릎의 굽힘(flexion)과 폄 (extension)동작이 원활하지 않아 충격을 흡수하는데 어려움이 있는 상태였다. 계단을 이용하여 이동할 때는 손잡이 레일을 잡고 계단을 오르고 내릴 수 있지만 왼 발만 사용하여 한 번에 한 칸씩 움직이며 달리거나 점프 동작을 수행하는데 어려움이 있었다. 이러한 보행의 문 제점 중 넘어지는 빈도와 무릎관절의 굽힘과 폄 동작이 현저하게 개선된 것으로 관찰되고, 계단을 오르내릴 때 좌우 양측 발을 모두 이용하여 교차하며 이동할 수 있 게 되었다. 또한 트레드밀에서의 보행과 달리기 그리고
스텝박스에서 내리는 동작 중 쿵쿵 거리는 소리가 현저 하게 감소된 것으로 보아 발목과 무릎관절에 전달되는 충격도 일정부분 흡수할 수 있는 능력이 향상된 것으로 생각된다. 특히 연구대상자 $\mathrm{A}$ 는 뇌병변장애와 지적장애 를 동반으로 가지고 있는 중복장애 아동임에도 불구하 고 이 연구에서 제시하고 있는 운동 프로그램을 반복적 으로 수행하며 모든 동작들을 스스로 인지하고 수행할 수 있었다. 이는 이 연구에서 제시하고 있는 신장성 근 수축운동 프로그램을 다양한 대상자에게 충분히 적용할 수 있을 것이라 생각한다. 연구대상자 $\mathrm{B}$ 는 평지에서의 보행 시 넘어지는 빈도가 감소되었으며 계단을 올라갈 때에는 주변의 도움을 받아야 할 정도로 이동능력에 어 려움이 있었지만 스스로 계단을 오르내릴 수 있을 정도 로 보행과 평형능력이 향상된 것으로 생각된다. 이는 신 장성 운동 프로그램 참여하기 전 한쪽(오른쪽)으로 쏠려 있던 비대칭성이 양쪽의 근력이 증가하여 불안정한 무게 중심이 안정화되고 이로 인한 고유수용감각이 향상되어 자세조절능력과 협응능력이 개선된 것으로 생각한다.

이러한 결과를 종합해볼 때 신장성 근수축운동 프 로그램이 뇌병변 장애아동의 보행과 평형능력의 향상 에 긍정적인 영향을 미치는 것으로 생각되며 일상생활 에서의 안전사고 예방과 독립적인 생활을 영위해 나아 가는데 큰 도움이 될 수 있을 것이라고 생각된다. 아울 러 뇌병변 장애아동의 운동 프로그램을 계획하고 지도 할 경우 다양한 신장성 근수축운동의 동작을 개발하고 적용할 필요가 있을 것으로 생각한다.

\section{결론}

이 연구는 12 주간 뇌병변 장애아동을 대상으로 신 장성 근수축운동 프로그램을 수행한 결과 보행능력 (6 $\mathrm{m}$ 걷기, $10 \mathrm{~m}$ 걷기, $3 \mathrm{~m}$ 뒤로 걷기, 4 개 계단 오르 기, 4 개 계단 내려가기)과 평형능력(눈뜨고 외발서기, 눈감고 외발서기) 개선에 긍정적인 효과가 있는 것으 로 나타났다. 하지만 이 연구는 뇌병변 장애아동 2 명 을 대상으로 한 사례연구이기 때문에 이 연구의 결과 와 제시하고 있는 신장성 근수축운동 프로그램의 구성 요소인 빈도, 강도, 시간 등을 일반화 하는데 한계가 있다. 이에 후속연구에서는 더 많은 대상자를 중심으 로 신장성 근수축운동 프로그램의 효용성을 밝히고 검 증 할 필요가 있을 것으로 생각한다. 


\section{Acknowledgments}

이 연구는 서원대학교 특별연구과제 연구비 지원을 받고 수행된 연구 임.

\section{Conflicts of Interest:}

The authors declare no conflict of interest.

\section{References}

1. Kim JM, Lee CH, Koo AR. A study on the effects of weighttransfer training upon the gait patterns of hemiplegic patients through visual and auditory feedback. Phys Ther Korea. 1995; 2(2):9-23.

2. Sharp SA, Brouwer BJ. Isokinetic strength training of the hemiparetic knee: effects on function and spasticity. ACRM. 1997; 78:1231-1236.

3. Marcucci A, Edouard P, Loustalet E, Anjou MC. Gautheron V, Deqache F. Efficiency of flexible de rotator in walking cerebral palsy children. Ann Phys Rehabil Med. 2011; 54(6):337-47.

4. Carr JH, Shepherd RB, Nordholm L, Lynne D. Investigation of a new motor assessment scale for stroke patients. Phys Ther. 1985; 65 (2): 175-80.

5. Leonard CT, Hirshfeld H, Forssberg H. The development of independent walking in children with cerebral palsy. Dev Med Child Neurol. 1991; 33:567-177.

6. Yoo HY, Kim SY, Jang HJ. The effects of treadmill gait training with flexible derotator of Femur orthosis on postural alignment of lower extremities and gait in children with cerebral palsy; single group repeated measure design. J Korean Soc Phys Med. 2014; 9 (1):1-10.

7. Son HY, Choi JD. The effect of weight shift training with joint mobilization on balance and gait velocity of hemiplegic patients. Phys Ther Korea. 2012; 19(1):10-18

8. Dettmann MA, Linder MT, Sepic SB. Relationships among walking performance, postural stability and functional assessments of the hemiplegic patient. Am J Phys Med.
1987; 66:77-90.

9. Hortobagyi T, Hill JP, Israel RG. Adaptive responses to muscle lengthening and shortening in humans. Journal of Applied Physiology.1996; 80:765-772.

10. Bobath, B. Adult hemiplegia: evaluation and treatment. 3rd ed. London, Heinemann. 1990

11. Ebbeling CB, Clarkson PM. Exercise-induced muscle damage and adaptation. Sports Medicine. 1989; 7:207234.

12. Rehm-Gelim SL, Light KE, Freund JE. Rehability of timedfunctional movement for clinical assessment of frail elderly population. Phy Occup Ther Geriat. 1997; 15 (1):1-19.

13. Sung KW. The effect of a health maintenance program on physical function and mental health of the elderly in nursing homes. J Korean Acad Nurs. 2007; 37(4):478489.

14. Bubbico A, Kravitz L. Eccentric exercise. IDEA Fitness Journal. 2010; 7 (9):50-59.

15. Ko SS, Jang SS, Lee SI, Byeon JM. The effect of lower limb functional exercise in an unstable ground on lower limb strength and the balance ability of encephalopathy teenagers. Korean Journal of Growth and Development. 2016; 24(3):249-257

16. Yoo KT, Lee MG, Sung SC. Effects of combined and aerobic exercise training on functional fitness, gait, and stability in hemiplegic stroke patients. KJSS. 2008; 19 (2):37-50.

17. Shin E, Song BH. The effect of task-oriented circuit program on motor function improvement of children with cerebral palsy. KSNT. 2012; 16(1):25-36

18. Ko MS, Sim YJ, Kim DH, Jeon HS. Effects of three weeks of whole-body vibration training on joint-position sense, balance, and gait in children with cerebral palsy: A randomized controlled study. Physiotherapy Canada, 2016; 68(2):99-105.

19. Cho C, Hwang W, Hwang S, Chung Y. Treadmill training with virtual reality improves gait, balance, and muscle strength in children with cerebral palsy. JEM. 2016; 238(3):213-218.

20. Kong SA, Yoo SH. Effects of a 12-week resistance exercise training on gait in ambulatory chronic hemiparetic 
stroke patients. IJASS. 2005; 16(4):90-104

21. Tarakci D, Ersoz HB, Tarakci E, Razak OA. The effects of nintendo Wii-Fit video games on balance in children with mild cerebral palsy. Pediatrics International. 2016; 58(10):1042-1050.

22. Del Valle A, Thomas CK. Firing rates of motor units during strong dynamic contractions. Muscle Nerve. 2005; 32:316-325.

23. Tesch PA, Dudley GA, Duvoisin MR, Hather BM, Harris, RT. Force and EMG signal patterns during repeated bouts of concentric or eccentric muscle actions. Acta Physiologica Scandinavia. 1990; 138: 263-271.
24. Johnson BA, Salzberg CL, Stevenson DAA systematic review: plyometric training programs of young children. JSCR. 2011; 29(9):2623-2633.

25. Kim YM, Kim TS, Jee YS, Yoon JH. Effects of 12-weeks plyometric training on motor nerve conduction velocity and knee isokinetic muscular functions in boys while attending community based soccer club. Journal of Sports and Leisure. 2012; 49: 981-990.

26. Gurfinkel VS, Lipshits MI, Lestienne FG. Anticipatory neck muscle activity associated with rapid arm movements. Neurosci. Lett. 1988; 94:104-108. 